\title{
Early Recognition and Diagnosis of Buried Bumper Syndrome: A Report of Three Cases
}

\author{
Johan Devia ${ }^{1}$ Juan Jose Santivañez, MD $^{2}{ }^{2}$ \\ Arturo Vergara ${ }^{5}$
1 Fundación Santa Fe de Bogotá, Intensive Care Unit, Universidad de Rosario, Bogotá, Colombia
2 Fundación Santa Fe de Bogotá, General Surgery, Universidad del
Rosario, Bogotá, Colombia
3 Universidad de Los Andes, Bogotá, Colombia
${ }^{4}$ Fundación Santa Fe de Bogotá, General Surgery, Universidad
Surcolombiana, Bogotá, Colombia
${ }^{5}$ Department of General Surgery, Fundación Santa Fe de Bogotá,
Bogotá, Colombia

Mario Rodríguez ${ }^{3}$

Sandra Rojas ${ }^{4}$

Manuel Cadena ${ }^{5}$

Surg J 2019;5:e76-e81.

\begin{abstract}
Address for correspondence Juan Jose Santivañez, MD, Department of Surgery, Fundación Santa Fe de Bogotá, Carrera 7B No. 123 - 90, Bogotá, Colombia (e-mail: juan.santivanez@urosario.edu.co).
\end{abstract}

\begin{abstract}
Buried bumper syndrome (BBS) was described as a complication of percutaneous endoscopic gastrostomy (PEG) that occurs when the internal stump of the probe migrates and is located between the gastric wall and the skin. The increase of compression between the internal stump and the external stump of the gastrostomy tube causes pain and the inability to feed. We present the cases of three patients with BBS managed by the metabolic and nutritional support department. These cases intend to illustrate one of the less frequent complications of PEG, clinical presentation, risk factors, diagnosis, and especially clinical management. Although there are no

Keywords

- buried bumper syndrome

- percutaneous endoscopic gastrostomy

- major complication

- internal stump defined gold standards for its management, the most important points in the management of this condition are early recognition, recommendations to avoid ischemic process at the moment of the insertion of the tube, specific care of the gastrostomy tube, and a periodic nutrition evaluation to avoid overweight, which causes traction and excessive pressure in the gastric wall. It is important for physicians to be aware of the recommendations to prevent BBS and its complications, especially in patients in whom communication can be difficult secondary to their pathologies and comorbidities.
\end{abstract}

\footnotetext{
(D) Johan Devia's ORCID is https://orcid.org/0000-0001-9126-1991.

(D) Juan Jose Santivañez's ORCID is https://orcid.org/0000-00019701-6575.

(1) Mario Rodríguez's ORCID is https://orcid.org/0000-0002-38951595.

(D) Sandra Rojas's ORCID is https://orcid.org/0000-0002-3284-6831.

(D) Manuel Cadena's ORCID is https://orcid.org/0000-0003-36312711.

(D) Arturo Vergara's ORCID is https://orcid.org/0000-0002-62183135.
}

received

August 7, 2018

accepted after revision

April 25, 2019
DOI https://doi.org/

10.1055/s-0039-1692148. ISSN 2378-5128.
Copyright @ 2019 by Thieme Medical Publishers, Inc., 333 Seventh Avenue, New York, NY 10001, USA. Tel: +1(212) 584-4662.
License terms

(c) (1) 
Since the introduction of percutaneous endoscopic gastrostomy (PEG) in the 1980 s by Gauderer et al, ${ }^{1}$ many advantages were observed of providing adequate nutritional support to patients with limited caloric intake due to the restriction of their underlying disease. ${ }^{2}$ However, despite being a safe and effective method, this procedure ${ }^{3}$ can present complications that are relatively rare and vary according to their presentation. These are divided into two groups: complications associated with the procedure itself (early), which include aspiration during the procedure, acute hemorrhage, intraperitoneal hematoma, and perforation of the small intestine or colon, and late complications, such as aortogastric fistula, leakage of gastric secretions through PEG, and buried bumper syndrome (BBS). ${ }^{4,5}$

We present the cases of three patients with BBS, emphasizing the importance of early diagnostic to avoid possible life-threatening complications. These cases intend to illustrate one of the less frequent complications of PEG, clinical presentation, risk factors, diagnosis, and especially clinical management.

\section{Case Report: Case 1}

A 95-year-old female patient from a geriatric home presented with a history of chronic obstructive pulmonary disease, type 2 diabetes mellitus, hypertension, hypothyroidism, breast adenocarcinoma treated with radical mastectomy and left ganglion emptying, and stroke 5 years ago. Due to her functional status, she required the placement of PEG. She was brought to the emergency room (ER) after having 2 days of burning abdominal pain around the stoma area associated with induration that was exacerbated with

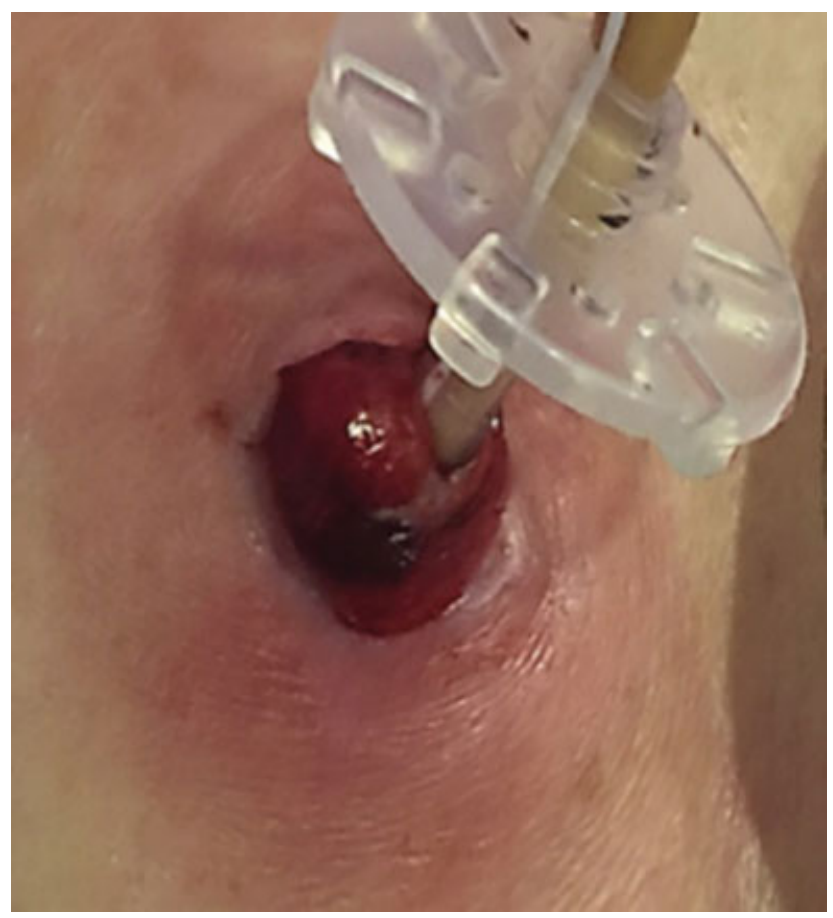

Fig. 1 Elevated peristomal edema with serohematic secretion around the catheter gastrostomy embedded in the subcutaneous tissue. the passage of the enteral nutrition. X-ray of the upper digestive tract and total abdominal ultrasound were performed without identifying any specific alterations.

She has persistent abdominal pain, which was, at that point, accompanied by redness with increased temperature around the stoma. Although she was in adequate general conditions with normal vitals, the elevated peristomal edema with serohematic secretion around the catheter gastrostomy was now embedded in the subcutaneous tissue accompanied by intense pain (-Fig. $\mathbf{1}$ ).

Given the gastrostomy mobilization, gastrostomy removal was performed by extracting the buried cannula simultaneously with pulling through of a new system. Antibiotics were in initiated, secretion stains were taken, and parenteral nutrition was ordered. The patient had adequate clinical improvement (-Fig. 2). Secretion stains revealed a multisensible Streptococcus agalactiae requiring 7 days of intravenous antibiotics. Enteral nutrition was initiated with adequate tolerance. The patient was discharged the next day.

\section{Case 2}

A 97-year-old female patient presented with a history of swallowing disorder secondary to stroke requiring PEG 2 months prior to admission. She was brought to the ER after having partial displacement of the gastrostomy tube, but tube permeability was maintained. No perilesional erythema or leakage was documented. At physical examination, the gastrostomy tube balloon was embedded into the subcutaneous tissue; the diagnosis of BBS was made. The gastrostomy tube balloon was deflated and then reinserted into the gastric cavity without complications. The patient was left under observation along with enteral nutrition reinitiated with adequate tolerance. There were no complications and no signs of inflammatory response, and the patient was discharged.

\section{Case 3}

A 76-year-old male patient transferred from a medium complexity hospital presented with dysphagia for solids

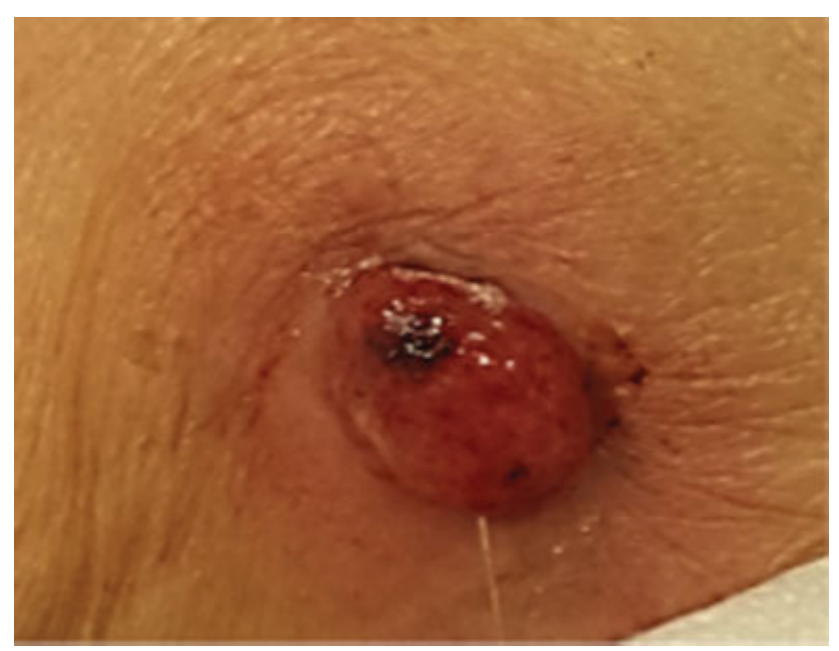

Fig. 2 Ostomy with decrease in erythema and without secretion. 


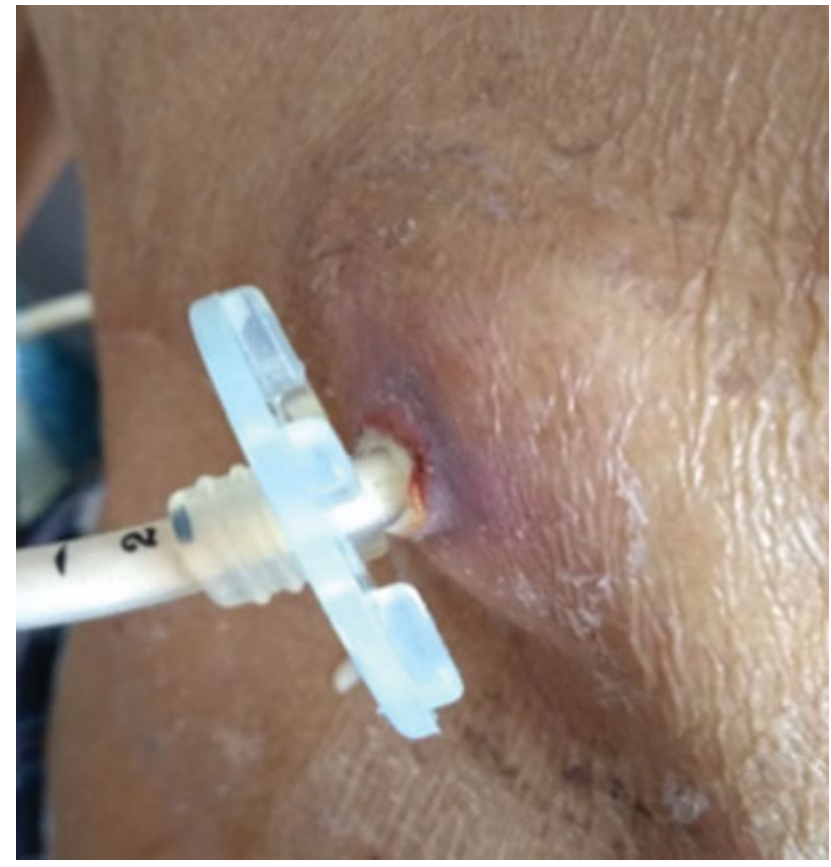

Fig. 3 Induration of stoma area associated with leakage through the stoma.

and liquids associated with weight loss and grade III malnutrition. He also had a history of benign esophageal stenosis and had a PEG placed from the institution remission. He was treated in the intensive care unit for an unresolved bronchoesophageal fistula that generated episodes of bronchoaspiration and recurrent pneumonias.

He presented with 2 hours of burning pain in the epigastrium around the stoma area associated with induration that was exacerbated by the passage of the enteral nutrition as well as leakage through the stoma without changes in skin color. Subsequent dysfunction of gastrostomy tube was also observed (-Fig. 3). Abdominal pain and gastrostomy tube dysfunction persisted. Physical examination showed an indurated lesion elevated by peristomal edema without secre- tions, and the gastrostomy tube was embedded into the subcutaneous tissue. Manual maneuvering managed to reinsert the internal gastrostomy stump without complications. Enteral nutrition was reinitiated, with adequate tolerance without new episodes of abdominal pain or leaking.

\section{Discussion}

BBS was first described in 1988 as a complication of PEG that occurs when the internal stump of the probe migrates and is located between the gastric wall and the skin. The increased compression between the internal stump and the external stump of the gastrostomy tube causes pain and the inability to digest. ${ }^{5,6}$ An ischemic process with subsequent necrosis of the gastric mucosa secondary to the excessive pressure exerted by the stump that fix the probe occurs, which weakens the gastric mucosa, and that together with hydrochloric acid and pepsin exacerbates the necrotic process, further weakening the mucosa and allowing migration of the internal stump to be buried between the gastric wall and the skin (-Fig. 4) ${ }^{7}$

With an incidence of approximately 0.3 to $2.4 \%,{ }^{8-11}$ it is considered a major late complication; however, there are documented cases on the appearance of this complication within 3 weeks after performing the procedure. ${ }^{8,12}$ In our institution during the last year, 32 percutaneous gastrostomies were performed, of which three cases of BBS were reported, accounting for the $0.96 \%$ incidence. This happens because the migration of the internal stump after the PEG has been performed ${ }^{13}$ secondary to excessive friction of the probe or because the external stump is fixed too tightly. ${ }^{14}$ Its appearance is favored by several risk factors such as: (1) excessive tension between the internal and external bumpers of the gastrostomy tube, (2) increase in hydrochloric acid, which produces physical alterations in the internal bumper, (3) inadequate size or material of the gastrostomy tube, ${ }^{15,16}$ (4) inadequate handling and care of the gastrostomy tube, and (5) patient comorbidities such as obesity and chronic cough. ${ }^{8}$

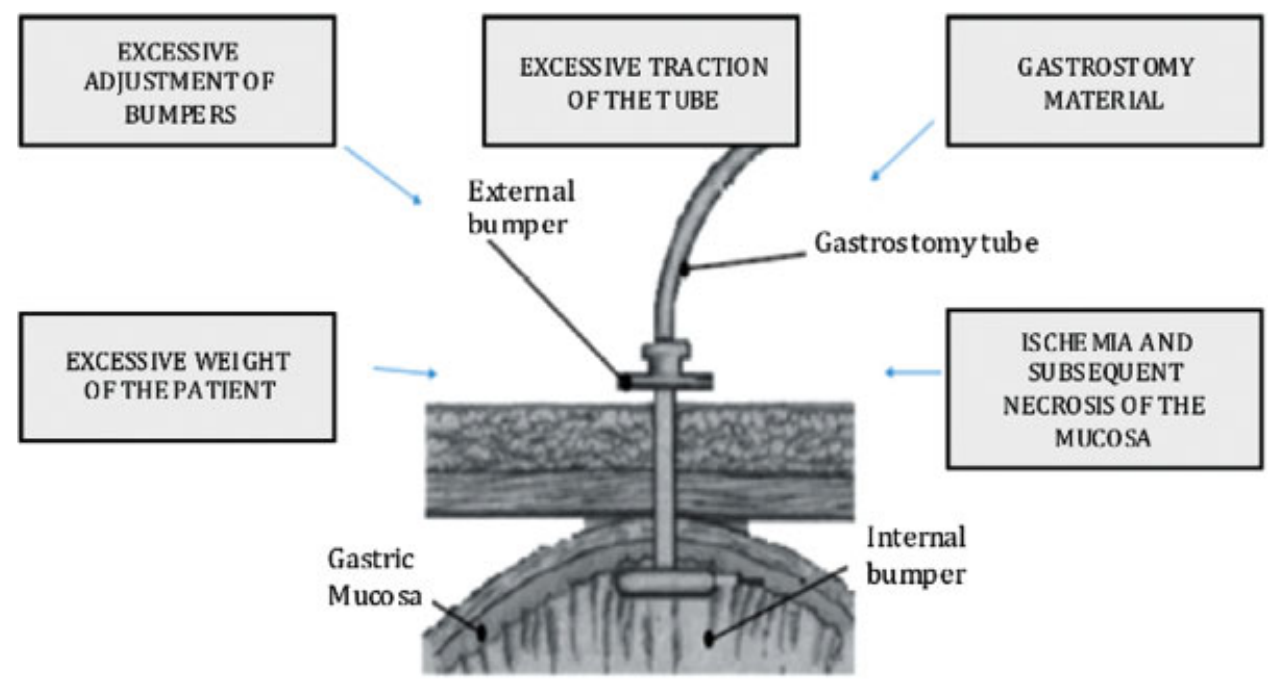

Fig. 4 Factors that lead to ischemia and necrosis of the mucosa, facilitating stump migration. ${ }^{48}$ 
The clinical presentation of BBS varies according to the degree of mucosa and gastric wall injury, as well as the immobilization and obstruction of the gastrostomy tube. ${ }^{17,18}$ However, more severe presentations of this complication may occur, such as the appearance of fistulas or necrotizing fasciitis, and these are presentations often due to the inability of the patients to manifest symptoms early due to their age or due to their clinical condition. ${ }^{19}$ The complications associated with BBS include perforation, peritonitis, 6,20,21 abdominal wall bleeding, ${ }^{22,23}$ and abdominal wall abscess, ${ }^{24}$ as well as necrosis secondary to pressure and gastric ulcers. ${ }^{25}$

Although the majority of these manifestations can be diagnosed clinically based on the history, the physical examination, and the failure to insert and rotate the PEG tube before replacing the external stump, ${ }^{26}$ the definitive diagnosis is made by endoscopy since it allows a more accurate localization. ${ }^{27}$ However, abdominal ultrasound, ${ }^{28}$ endosonography, ${ }^{29}$ and abdominal computed tomography (CT) can also be used as diagnostic tools. ${ }^{30}$ The findings on endoscopy, which should be performed in all cases in which BBS is suspected, vary according to the duration of symptoms and the time of tube insertion. In early stages, a normal gastric mucosa can be observed with pressure ulcers located under the stump, whereas in more advanced stages, it is common to find an edematous mucosa with an overgrowth of tissue that lines the gastrostomy stump. ${ }^{31}$

Orsi et $\mathrm{al}^{32}$ developed the following classification based on the migration of the internal stump and symptomatology:

- Grade 1: partial migration-asymptomatic presentation or mild symptoms such as abdominal pain or ostomy infection.

- Grade 2: subtotal migration-the patient presents with dysfunction of the tube and extravasation of the nutrition.

- Grade 3: total migration-manifested by tube obstruction.

Although it has been a classification frequently used to serve as a guide for treatment, recently Richter-Schrag et al $^{33}$ postulated a new classification based on endoscopic findings:

- IA: extracorporeal or subcutaneous tissue.

- IB: perforated.

- II: partially visible to the mobilization.

- III: totally visible at mobilization, with or without fistula.

- IV: deep, without level of mobilization, with or without fistula.

This classification is much descriptive in terms of the position of the internal stump, although the classification proposed by Orsi et al is more frequently used because it provides simpler information about the location of the internal limit and associated symptomatology, and serves as a guide for treatment.

Regarding the treatment of BBS, despite the contribution provided by the location of the internal bumper, the clinical presentation and comorbidities of the patient also play important roles. Therefore, the management found in the literature has been case reports with individual treatment, ${ }^{7}$ in which endoscopic, surgical, and even radiological approaches are described. ${ }^{34-36}$ However, the management depends on two factors mainly: the type of gastrostomy and the degree of depth to which the internal stump migrates, ${ }^{37}$ as this defines the initial approach. If there are no symptoms, the internal stump should always be removed once SBB is diagnosed since failure to do so may lead to the appearance of symptoms and the progression of complications, which make the treatment much more complex. ${ }^{38}$ Currently there are no guidelines on which we could base the treatment. We can base our intervention in a conservative approach, the endoscopic therapy, or the surgical therapy. Considering the classification by Orsi et $\mathrm{al}^{32}$ for treatment purposes, grade 1 has always benefited by an endoscopic approach with external extraction, whereas grades 2 and 3 require a surgical approach.

With the endoscopic approach, if the internal stump is collapsible or malleable, the initial recommendation is to remove the gastrostomy by external extraction ${ }^{39}$; however, a modification of this technique has been described, in which the gastrostomy tube is cut, through which a guide is passed and travels to the gastric cavity, subsequently, the guide wire is trapped endoscopically and is removed through the oral cavity, where it is attached to a new gastrostomy tube. The portion of the guide wire that is in the abdominal cavity is pulled so that the new gastrostomy tube is inserted into the abdominal wall and, in turn, pushes out the old gastrostomy tube through the abdominal wall. ${ }^{40}$ However, this procedure is usually difficult, and in inexperienced hands may result in additional injury. If the internal stump is not collapsible, other techniques for the extraction of the gastrostomy tube have been described, such as the "T technique" by Boyd et $\mathrm{al}^{41}$ and the "needle-knife" technique by Ma et $\mathrm{al}^{17}$ for cases in which the internal stump is partially or superficially buried.

When the internal stump cannot be removed by an endoscopic approach, surgical approaches have been described, in which it can be released through a skin incision, ${ }^{42}$ or even laparoscopy, when it has migrated to the stomach and an endoscopic extraction is not possible. ${ }^{43}$ Likewise, cases have been described in which minimally invasive $^{44}$ and radiological techniques are used for their extraction. $^{45}$

Although there is no defined gold standard in the management of BBS, the most important aspect of treating this condition is early recognition. Ischemic process should be avoided at the time of tube insertion, specific care should be taken of the gastrostomy tube, and a periodic nutrition evaluation should be made to avoid overweight, which causes traction and excessive pressure on the gastric wall. For the prevention of BBS, it is recommended to leave a space of $1.5 \mathrm{~cm}$ between the external stump of the gastrostomy tube and the skin, as well as to externally mobilize and loosen every 2 days. ${ }^{37}$ It is also important to provide better care for the gastrostomy system, to constantly follow up these patients, and to encourage effective communication between nutrition specialists, nurses, and the patients and their family. ${ }^{46,47}$ 


\section{Conclusion}

BBS is an unusual complication secondary to PEG; nevertheless, its early recognition is vital for providing the most appropriate approach as well as avoiding its harmful consequences and multiple negative effects on the gastrointestinal tract. Despite the age and multiple comorbidities, the medical history and physical examination were enough to make the diagnosis of BBS. Among the clinical presentations described in the literature, abdominal pain, immobilization of the gastrostomy tube, and inability to pass the enteral nutrition solution were constant in our patients. There is no evidence of leakage or fistulas; however, when leakage or fistulas are present, they occur in advanced cases due to the delay in consultation or in neurological patients and/or advanced age.

\section{Conflict of Interest \\ None.}

\section{References}

1 Gauderer MW, Ponsky JL, Izant RJ Jr. Gastrostomy without laparotomy: a percutaneous endoscopic technique. J Pediatr Surg 1980;15(06):872-875

2 Vargas M, Wilches A, Loochkartt A. Revisión de Gastrostomía Endoscópica Percutánea (PEG): Experiencia de Tres años en atención hospitalaria. CIRUPED 2012;2(01):44-49

3 Kamalesh NP, Prakash K, Ramesh GN. Wandering gastrostomy. Indian J Surg 2016;78(02):144-146

4 Kurek K, Baniukiewicz A, Świdnicka-Siergiejko A. Buried bumper syndrome: a rare complication of percutaneous endoscopic gastrostomy. Wideochir Inne Tech Malo Inwazyjne 2015;10(03): 504-507

5 Khalil Q Kibria R, Akram S. Acute buried bumper syndrome. South Med J 2010;103(12):1256-1258

6 Klein S, Heare BR, Soloway RD. The "buried bumper syndrome": a complication of percutaneous endoscopic gastrostomy. Am J Gastroenterol 1990;85(04):448-451

7 Moreno N, Otero W, Gómez M, Bula R, Otero E. Síndrome de "buried bumper": desenterrando la solución. Rev Colomb Gastroenterol 2007;22(01):51-56

8 Geer W, Jeanmonod R. Early presentation of buried bumper syndrome. West J Emerg Med 2013;14(05):421-423

9 Pop GH. Buried bumper syndrome: can we prevent it? Pract Gastroenterol 2010;34(05):8-13

10 Schapiro GD, Edmundowicz SA. Complications of percutaneous endoscopic gastrostomy. Gastrointest Endosc Clin N Am 1996;6 (02):409-422

11 Mathus-Vliegen LM, Koning H. Percutaneous endoscopic gastrostomy and gastrojejunostomy: a critical reappraisal of patient selection, tube function and the feasibility of nutritional support during extended follow-up. Gastrointest Endosc 1999;50(06): 746-754

12 Lin HS, Ibrahim HZ, Kheng JW, Fee WE, Terris DJ. Percutaneous endoscopic gastrostomy: strategies for prevention and management of complications. Laryngoscope 2001;111(10): 1847-1852

13 Boldo E, Perez de Lucia G, Aracil J, Martin F, Martinez D, Miralles J, et al. Early buried bumper syndrome. Internet J Gastroenterol 2006;5(01):1-5

14 Rino Y, Tokunaga M, Morinaga S, et al. The buried bumper syndrome: an early complication of percutaneous endoscopic gastrostomy. Hepatogastroenterology 2002;49(46):1183-1184
$15 \mathrm{Vu}$ CK. Buried bumper syndrome: old problem, new tricks. J Gastroenterol Hepatol 2002;17(10):1125-1128

16 Fouch P, Woods C, Talbert G, Sanowski R. A critical analysis of the Sachs-Vine gastrostomy tube: a review of 120 consecutive procedures. J Gastroenterol 1988;83(08):812-815

17 Ma MM, Semlacher EA, Fedorak RN, et al. The buried gastrostomy bumper syndrome: prevention and endoscopic approaches to removal. Gastrointest Endosc 1995;41(05):505-508

18 Vargo J, Ponsky J. Percutaneous endoscopic gastrostomy: clinical applications. Medscape Gastroenterol 2000. Available at: http:// www.medscape.com/viewarticle/407957. Accessed August 12,2019

19 Biswas S, Dontukurthy S, Rosenzweig MG, Kothuru R, Abrol S. Buried bumper syndrome revisited: a rare but potentially fatal complication of PEG tube placement. Case Rep Crit Care 2014; 2014:634953

20 Foutch PG, Talbert GA, Waring JP, Sanowski RA. Percutaneous endoscopic gastrostomy in patients with prior abdominal surgery: virtues of the safe tract. Am J Gastroenterol 1988;83(02): 147-150

21 Anagnostopoulos GK, Kostopoulos P, Arvanitidis DM. Buried bumper syndrome with a fatal outcome, presenting early as gastrointestinal bleeding after percutaneous endoscopic gastrostomy placement. J Postgrad Med 2003;49(04):325-327

22 Dormann AJ, Müssig O, Wejda B, Huchzermeyer H. Successful use of a button system in "buried bumper" syndrome [. in German]. Dtsch Med Wochenschr 2001;126(24):722-724

23 Van Weyenberg SJ, Lely RJ. Arterial hemorrhage due to a buried percutaneous endoscopic gastrostomy catheter. Endoscopy 2013; 45(2, Suppl 2 UCTN):E261-E262

24 Johnson T, Velez KA, Zhan E. Buried bumper syndrome causing rectus abdominis necrosis in a man with tetraplegia. Spinal Cord 2010;48(01):85-86

25 Tang S. Percutaneous endoscopic gastrostomy tube replacement. Video J Encycl GI Endosc 2014;2(02):70-73

26 Bhat G, Suvarna D, Pai CG. Acute buried bumper syndrome: an endoscopic peg tube salvage approach. Indian J Med Sci 2010;64 (05):234-236

27 Gencosmanoglu R, Sen-Oran E. Two-step approach in the treatment of buried bumper syndrome as a late complication of percutaneous endoscopic gastrostomy. Internet J Gastroenterol 2002;2(02):1-5

28 Tanaka Y, Akahoshi K, Motomura Y, et al. Pretherapeutic evaluation of buried bumper syndrome by endoscopic ultrasonography. Endoscopy 2012;44(2, Suppl 2 UCTN):E162

29 Braden B, Brandstaetter M, Caspary WF, Seifert H. Buried bumper syndrome: treatment guided by catheter probe US. Gastrointest Endosc 2003;57(06):747-751

30 Schrag SP, Sharma R, Jaik NP, et al. Complications related to percutaneous endoscopic gastrostomy (PEG) tubes. A comprehensive clinical review. J Gastrointestin Liver Dis 2007;16(04): 407-418

31 Oner OZ, Gündüz UR, Koç U, Karakas BR, Harmandar FA, Bülbüller $\mathrm{N}$. Management of a complicated buried bumper syndrome with a technique involving dye test, cannulation, and extraction. Endoscopy 2014;46(1, Suppl 1 UCTN):E238-E239

32 Orsi P, Spaggiari C, Pinazzi O. Is the buried bumper syndrome a buried problem? Personal experience about a different therapeutic approach and prevention possibilities. Riv Ital di Nutr Parenter ed Enterale 2002;20(Suppl 3):124-131

33 Richter-Schrag H, Fischer A. Buried-bumper-Syndrom: Eine neue Klassifikation mit Therapiealgorithmus. Der Chir 2015:963-969

34 Cyrany J, Rejchrt S, Kopacova M, Bures J. Buried bumper syndrome: a complication of percutaneous endoscopic gastrostomy. World J Gastroenterol 2016;22(02):618-627

35 Kejariwal D, Aravinthan A, Bromley D, Miao Y. Buried bumper syndrome: cut and leave it alone!. Nutr Clin Pract 2008;23(03): 322-324 
36 Rahnemai-Azar AA, Rahnemaiazar AA, Naghshizadian R, Kurtz A, Farkas DT. Percutaneous endoscopic gastrostomy: indications, technique, complications and management. World J Gastroenterol 2014;20(24):7739-7751

37 Enestvedt BK, Jorgensen J, Sedlack RE, et al; ASGE Training Committee 2013-2014. Endoscopic approaches to enteral feeding and nutrition core curriculum. Gastrointest Endosc 2014;80(01): 34-41

38 Blumenstein I, Shastri YM, Stein J. Gastroenteric tube feeding: techniques, problems and solutions. World J Gastroenterol 2014; 20(26):8505-8524

39 Lee TH, Lin JT. Clinical manifestations and management of buried bumper syndrome in patients with percutaneous endoscopic gastrostomy. Gastrointest Endosc 2008;68(03):580-584

40 Venu RP, Brown RD, Pastika BJ, Erikson LW Jr. The buried bumper syndrome: a simple management approach in two patients. Gastrointest Endosc 2002;56(04):582-584

41 Boyd JW, DeLegge MH, Shamburek RD, Kirby DF. The buried bumper syndrome: a new technique for safe, endoscopic PEG removal. Gastrointest Endosc 1995;41(05):508-511

42 Frascio F, Giacosa A, Piero P, Sukkar SG, Pugliese V, Munizzi F. Another approach to the buried bumper syndrome. Gastrointest Endosc 1996;43(03):263-264
43 Boreham B, Ammori BJ. Laparoscopic percutaneous endoscopic gastrostomy removal in a patient with buried-bumper syndrome: a new approach. Surg Laparosc Endosc Percutan Tech 2002;12 (05):356-358

44 Müller-Gerbes D, Aymaz S, Dormann AJ. Management of the buried bumper syndrome: a new minimally invasive technique-the push method [in German]. Z Gastroenterol 2009;47 (11):1145-1148

45 Crowley JJ, Vora D, Becker CJ, Harris LS. Radiologic removal of buried gastrostomy bumpers in pediatric patients. AJR Am J Roentgenol 2001;176(03):766-768

46 Sheers R, Chapman S. The buried bumper syndrome: a complication of percutaneous endoscopic gastrostomy. Gut 1998;43(04): 586

47 El AZ, Arvanitakis M, Ballarin A, Devière J, Le Moine O, Van Gossum A. Buried bumper syndrome: low incidence and safe endoscopic management. Acta Gastroenterol Belg 2011;74(02): $312-316$

48 Gençosmanoğlu R, Koç D, Tözün N. The buried bumper syndrome: migration of internal bumper of percutaneous endoscopic gastrostomy tube into the abdominal wall. J Gastroenterol 2003;38(11): 1077-1080 